\title{
The Combination of Aeration and Filtration System in Reducing Water Pollution: An Experimental Study
}

\author{
Ronny $^{\mathrm{a}}$, Bun Yamin M. Badjuka ${ }^{\mathrm{b}}$, Jasman $^{\mathrm{c}}$, Rusli $^{\mathrm{d}}$, Hari Basuki Notobroto ${ }^{\mathrm{e}}$ \\ ${ }^{a}$ Department of Environmental Health, Poltekkes Kemenkes Makassar, Makassar 90222, Indonesia \\ E-mail: ronnymuntu@gmail.com \\ ${ }^{b}$ Department of Environmental Health, Poltekkes Kemenkes Gorontalo, Gorontalo 96135, Indonesia \\ E-mail: bunyaminbadjuka@gmail.com \\ ${ }^{c}$ Department of Environmental Health, Poltekkes Kemenkes Manado, Manado 95263, Indonesia \\ E-mail: jasman067@gmail.com \\ ${ }^{d}$ Department of Pharmacy, Poltekkes Kemenkes Makassar, Makassar 90222, Indonesia \\ E-mail: rusfar67@yahoo.com \\ ${ }^{e}$ Department of Biostatistics and Population, Universitas Airlangga, Surabaya 60115, Indonesia \\ E-mail: harinotobroto@gmail.com
}

\begin{abstract}
This study aims to determine and analyze the combination of aeration systems with Multiple Tray Aerator and Filtration with Rapid Sand Filter in reducing iron (Fe) content in water. The source of water used is shallow well water that is still used by the community. The research design used in this study was One-Group Pretest-Posttest Design. The study located in Pangkep Regency, South Sulawesi Province, and then for the second location in Manado City, North Sulawesi Province. The number of samples with the type of experimental research was 10 with the Purposive Random Sampling technique. The instruments used in this research are Multiple Tray Aerator and Rapid Sand Filter. The results showed that the percentage of reduction using a combination of aeration and filtration systems when averaged for the two study sites, a rate of 58.50 percent obtained. The increase in iron ( $\mathrm{Fe}$ ) content, one of which is influenced by the climate at the research location, will directly increase the water temperature sources in this study, namely surface wells, which will dissolve more iron ( $\mathrm{Fe}$ ) levels. Another factor that affects iron (Fe) levels is the difference in research locations, namely on islands and coasts. This can be seen in the differences in the results of iron (Fe) levels obtained at the two research locations. Those who wish to conduct further study should pay attention to the tool's type and ability and design a more accurate model to minimize energy and cost and a more concrete form.
\end{abstract}

Keywords — contamination; groundwater; Iron (Fe); multiple tray aerators; rapid sand filters.

\section{INTRODUCTION}

From now on, all groups have begun to realize the problem of water. The threat of water crisis is in front of us due to climate change, infrastructure development that is not environmentally friendly, and many wrong human actions that cause environmental damage [1]. The use of groundwater needs to be done carefully, and the concepts of development must also be considered so as not to further damage the natural ecosystem. Water, as a component of the environment, will affect and be influenced by other components. Poor quality water will cause the environment to be wrong so that it will affect the health and safety of humans and other living things [2]. A decrease in water quality will reduce the usability, usability, productivity, carrying capacity, and carrying capacity of water resources, ultimately reducing natural resources [3]. To get good water according to specific standards, now it becomes an expensive item because water has been polluted by various kinds of waste from various human activities so that in quality, water resources have decreased, likewise in terms of quantity, which has been unable to meet the increasing needs.

The results of an analysis released by the World Resources Institute (WRI) mention that as many as 12 countries that are facing an imbalance between water supply and those needs are in the Middle East and North Africa. Others are in India, Pakistan, San Marino in Europe, 
Botswana in Africa, and Turkmenistan in Central Asia [4]. The shortage of water stocks has the potential to lead to severe water crisis conditions in the coming years. Hot air conditions and the start of reduced water supply have pushed countries in the Middle East and North Africa region to crisis conditions. Qatar is the country most at risk from water scarcity and relies heavily on seawater desalination systems to supply drinking water to the public and industry.

The results of projections made by the National Planning Agency of the Republic of Indonesia predict that raw water scarcity will occur in several regions in Indonesia. It happens due to the impact of global climate change and forest destruction. The area of water-critical areas in 2045 predicted to reach 9.6 percent or an increase of 3.6 percent compared to 2000. As the fourth most populous country in the world, the availability of clean water that has not evenly distributed is an important issue because it affects all aspects of life, starting from health to public welfare. Easy access to clean water also believed to be a way to break the poverty chain. Unfortunately, the improvement of Indonesia's economy over the past 20 years has not been accompanied by equitable access to clean water. As many as 33.4 million people lack clean water, and 99.7 million lack access to proper sanitation facilities. Data from the Central Statistics Agency said that the achievement of access to safe water in 2019 in Indonesia reached 72.55 percent. This figure is still below the Sustainable Development Goals (SDGs) target of 100 percent.

In Indonesia, shallow wells are a method of extracting groundwater widely applied in rural areas because it is easy to manufacture and can be carried out by the community itself with simple equipment and low cost. One source of water that can utilize is groundwater or well water. Well water is shallow groundwater usually found at a depth of 15 meters. As one of the sources used for drinking water, water considered quite good, while for the quantity, it does not depend too much on the seasons in the surrounding environment. If the rainy season occurs, the water debit will increase, and vice versa, the water debit will decrease if there is summer. Even in some types of soil, there is often a drought in surface wells [5].

Dug wells (shallow wells) are one of the most common and widespread constructions of wells used to take groundwater for small communities and individual houses as drinking water with a depth of 7-10 meters from ground level [6], [7]. Dug wells provide water that comes from layers of soil that are relatively close to the surface of the soil and are therefore easily exposed to contamination through seepage. Generally, seepage comes from human and animal waste disposal sites, namely latrines, as well as from the well waste itself because the floor or sewage is not waterproof. The state of construction and ways of extracting well water can be a source of contamination, for example, wells with open construction and taking water with buckets.

In terms of health, the use of dug wells is not good if the way of making not considered, but to minimize the possibility of pollution can seek prevention, these precautions can meet by taking into account the physical conditions of the well based on the conclusions of the opinion of several experts in this field, including the location of the well not less than 10 meters from the pollutant source, the floor of the well is at least 1 meter in diameter distance from the well wall and water-resistant, sewerage at least 10 meters and permanent, the height of the well's lip 0.8 meters, have a ring (wall) of a well of at least 3 meters and have a strong and tightly closed well.

The increasing activity of the community tends to increase consumption of the needs needed so that it causes increased waste disposal, especially household waste that generated [8]. Indiscriminate disposal of household waste is one of the causes of the decline in groundwater quality. Water sources have widely used for domestic, agricultural, industrial, fisheries, power generation, and others. Utilization of water sources, in addition to meeting the quantity and quality, must also meet water quality criteria according to their usage. The most important water use is the agricultural sector, which requires a supply of about 70 percent, then the industry 20 percent for energy and Manufacturing needs, 10 percent for households, and 1 percent for daily drinking. The water crisis, especially for consumption, will continue to threaten if the central and regional governments do not take strategic steps to prevent it. Mapping of water-prone areas needs to be done, slowing the destruction of ecosystems increasingly intensified.

Furthermore, restrictions on land-use change due to the invasion of housing business need to be also limited [9], [10]. The problem of clean water is dangerous, so it needs a very serious one too. The government is serious in overcoming all the triggering factors of the water crisis, is serious about making regulations about the restriction of land-use change, and is also severe about guaranteeing and ensuring that people have adequate access to the fulfillment of clean water so that there is no longer any unrest due to limited water resources.

In general, a system of clean water service providers in Indonesia uses a communal system with piped networks as a characteristic of a modern, clean water supply system. However, this system has not reached all regions, so this system has not reached some remote residential areas. Alternative water sources are used that come from groundwater to meet the needs of clean water in the environment. However, most groundwater sources that users are still unfit for use as clean water. High concentrations of iron and chloride in water is one of the least suitable for use. Therefore, we need instruments that are practical and easy to use to reduce the level of concentration of pollution in the water. Aeration is one of the ways to treat clean physical water, by adding air or oxygen to the water by spraying water into the air or by giving bubbles of fine air to the bottom of the surface. Aeration chose because it does not require a large place; its shape and design are simple and easy to operate. The filtration process aims to filter out the suspensions in the water. The filtration process can be done with membrane technology, but it can also use other media such as sand, gravel. In this membrane filtration process technology uses several types namely Multi-Media Filter, UF (Ultrafiltration) System [11]-[13], NF (Nanofiltration) System [14]-[17], MF (Microfiltration) System [18]-[20], RO (Reverse Osmosis) System [14], [16], [21], [22]. All types of filtration have advantages and disadvantages, both in use and price. 
The recommended Iron $(\mathrm{Fe})$ concentration requirement based on the standard clean water standard of the Regulation of the Minister of Health of the Republic of Indonesia is 1.0 $\mathrm{mg} / \mathrm{l}$. If the concentration of dissolved iron in water exceeds, this limit will cause physical interference caused by the presence of dissolved iron in water is the emergence of color, odor, taste and can cause health problems. This stability allows them to withstand changes and remain constant in any water, except water polluted by industry and human waste [23]. Based on various water sources, many people use freshwater that comes from groundwater as meeting their daily needs. Water is an essential resource to support life; the presence of water is sufficient to meet the quantity requirements in quantity but also has good quality [24]. Often the community views water needs as being sufficiently fulfilled if there is a sufficient amount, while the quality is of little concern. From this description, this study conducted aiming to determine the effectiveness of the use of the Multiple Tray Aerator and Rapid Sand Filter System in reducing the concentration of Iron $(\mathrm{Fe})$ in surface water, so that it can use as a source of water for use.

\section{MATERIALS AND METHOD}

\section{A. Materials}

Water treatment is a technical effort undertaken to change the nature of water. The purpose of water treatment is to reduce turbidity, improve the degree of acidity, reduce odors, and reduce and kill microorganisms in water so that the water is clear and odor-free [30]. The level of intensity of water treatment depends on the quality of the water to treat. The instrument used in this research is a combination of Multiple Tray Aerator and Rapid Sand Filter, aiming to reduce the concentration of iron $(\mathrm{Fe})$ and chloride $(\mathrm{Cl})$ in water from shallow wells. The shape and composition of the research instrument instruments can be seen in the picture as follows:

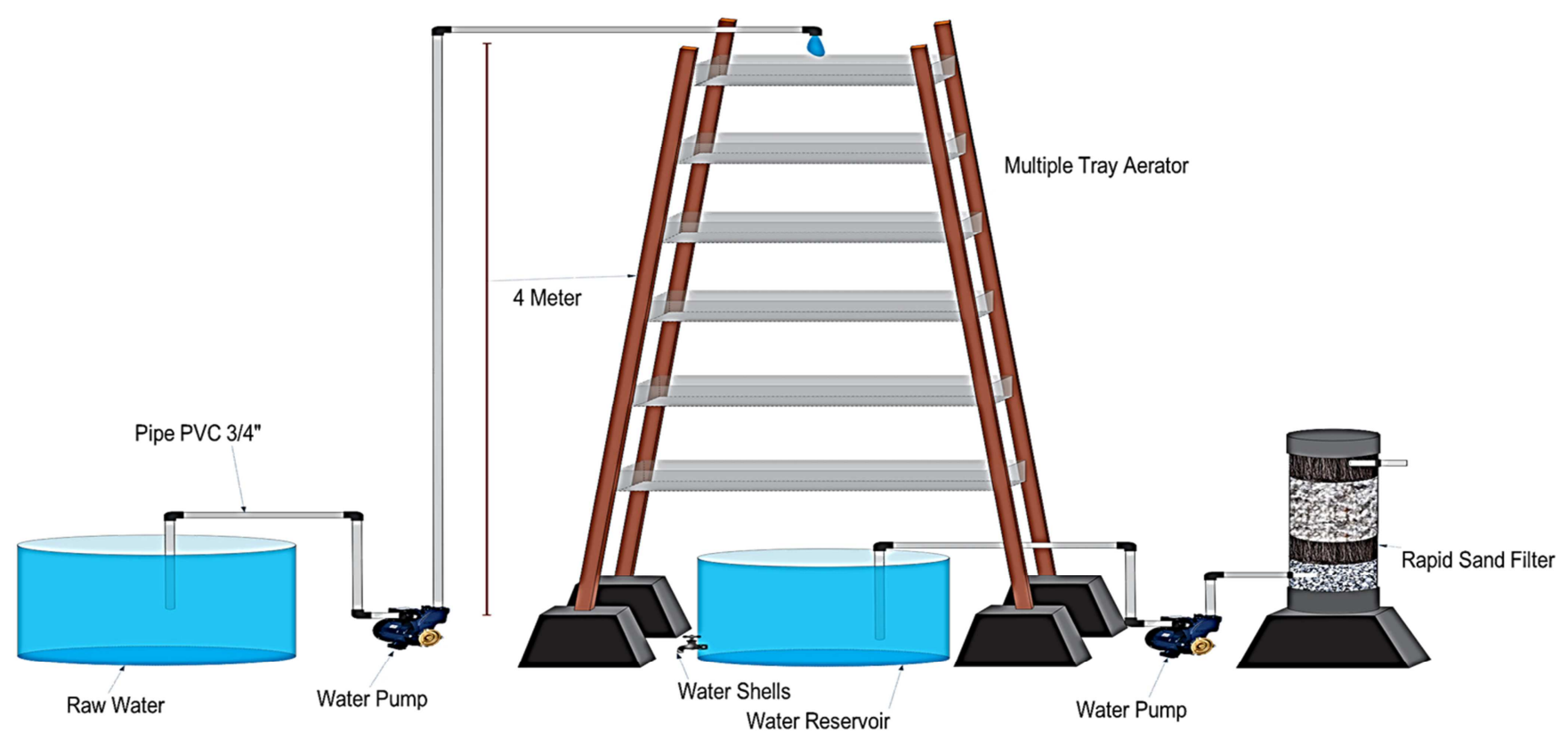

Fig. 1 Multiple Tray Aerator and Rapid Sand Filter Instruments

1) Multiple Tray Aerator: The aerator tray consists of several empty trays that will pass water to the next tray up to the collection basin. The equitable distribution of water above the tray is essential to improve efficiency. Some aerator trays use coarse media such as charcoal, stone, or ceramic balls with a 2-6 inches diameter. The grinding media is placed on top of the tray to increase gas exchange efficiency and distribution. Oxygen buildup can accelerate the oxidation process in water. The distance between each shelf is usually between 30 to $75 \mathrm{~cm}$, and the flow of water flows between $50-75 \mathrm{~m}^{3} /$ day [31]. The distance between the shelves varies between 30 and $45 \mathrm{~cm}$, and the size of the media is $2.5-15 \mathrm{~cm}$. In this research, the distance between the tray aerator tray is $60 \mathrm{~cm}$, with a total height of 4 meters. Then, the tray aerator tray's surface area ranges from $400-$ 900 square meters [32]. This aeration process needs to be done when raw water is processed from well water by using submersible pumps that flow into the aerator inlet through pipes, and then the water is sprayed through the main pipe with a split pipe. At that time, waterfalls through hollow trays aim to add oxygen to the raw water and precipitate the water's iron. After that, the water passes through the tray, then the water goes down through the aerator outlet pipe and into the filter bath and can then be distributed.

2) Rapid Sand Filter: The media used for the Rapid Sand Filter process is composed of natural silica sand, anthracite, or garnet sand, which have variations in size, shape, and chemical composition. The filter base consists of a pipeline system composed of lateral and manifolds to drain treated water whose received water is received through the orifice hole placed on the lateral pipe-the use of manifold and lateral aims so that the distribution evenly distributed. When the filtration process occurs, there is a decrease in production water discharge due to clogging or compression by filtered impurities and retained on the media, causing the pore diameter to shrink. 


\section{B. Method}

One-Group Pretest-Posttest Design is a model used in research conducted. In the One-Group Pretest-Posttest Design, the dependent variable measured as one group before (pre-test) and after (post-test) treatment given. After treatment given to the group, the values before and after the treatment are compared. The advantage of this experiment is that we can compare values before and after treating the same sample using the same instrument [25].

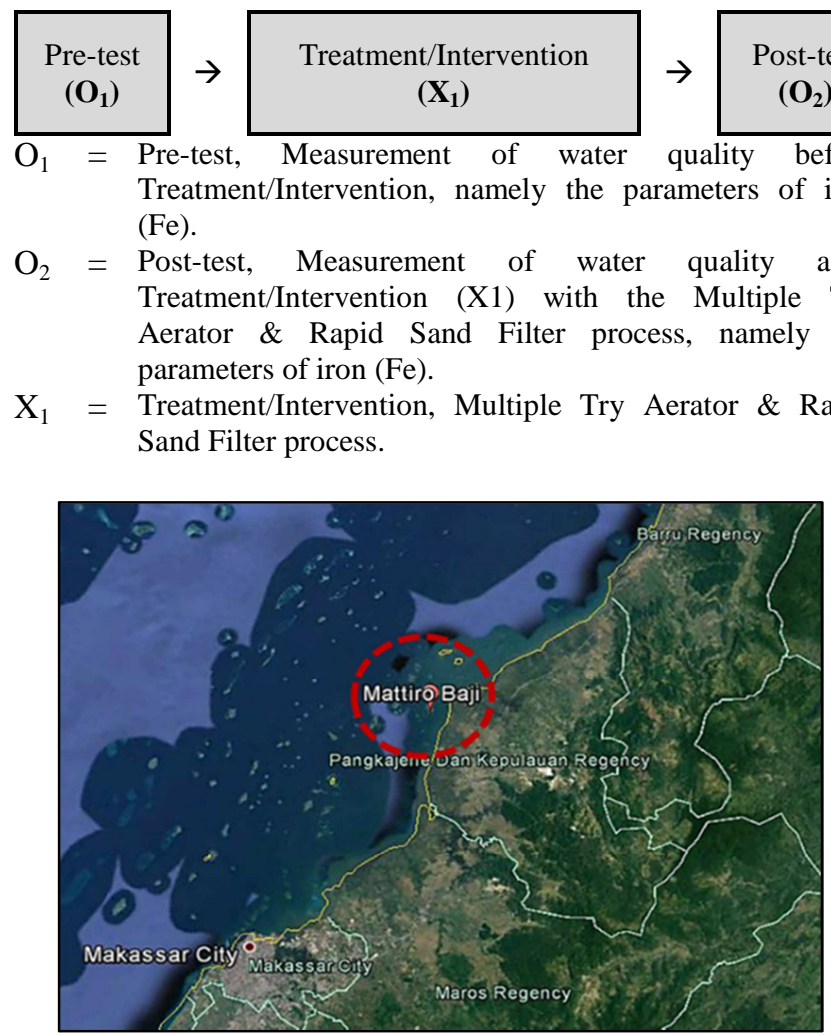

(a)
Experimental research methods are considered most suitable to determine the effect of using research tools or instruments on the research object. As a scientific study, researchers manipulate and control one or more independent variables and observe the dependent variables to find variations that appear together to use these independent variables. Further explained, the variable manipulated is called the independent variable, and the variable whose effect will see is called the dependent variable [26].

\section{Study Location}

This research was conducted in two locations that have different conditions. The first location is in one of the islands included in the administrative area of the Pangkep Regency, namely Mattiro Baji Island. The second location is in the coastal waters of the City of Manado. The use of clean water in both locations is relatively high, considering that the government prepares not all areas within reach of clean water.

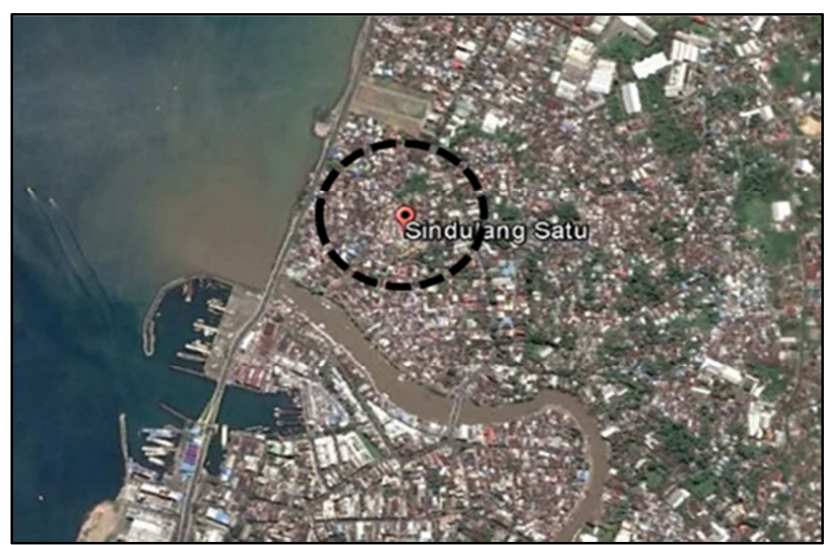

(b)

Fig. 2 Location Study, (a) Sapuli Island; (b) Sindulang Satu Urban Village.

The first location was in South Sulawesi Province, precisely on Sapuli Island, Mattiro Baji Village, Pangkep Regency with coordinates of $4^{\circ} 45^{\prime} 59.9^{\prime \prime} \mathrm{S}$ and $119^{\circ} 27^{\prime}$ 47.2" E. Then the second location was in North Sulawesi Province, precisely Sindulang Satu Urban Village, Tuminting District, Manado City with coordinates $1^{\circ} 30^{\prime}$ 02.7" N and $124^{\circ} 50^{\prime} 34.6^{\prime \prime} \mathrm{E}$ (Figure 2).

\section{Population and Sample}

The population is the whole of the object or subject of research. Populations whose elements have the same characteristics so that the amount is not quantitatively disputed [27]. This population dug well water, which is located and used by the community for daily activities in the Sapuli Islands, Pangkep Regency, and Sindulang Satu, Manado City. The sample is part of the quantity and characteristics possessed by the population. If the population is significant, and researchers may not study everything in the population. According to Roscoe and Diehl, in his book Fundamental Research Statistics for the Behavioral Sciences, recommending that the number of samples for experimental research is 10-20 samples [28], [29]. This study used ten samples for each experimental parameter by taking purposive random sampling techniques and dug well water sources used by the community.

\section{E. Data Collection}

Primary data were obtained from direct measurements of iron $(\mathrm{Fe})$ and chloride concentration of shallow well water at the study site in Pangkep Regency and Manado City. Data obtained in the study at each location and research point, then the data concentration of iron $(\mathrm{Fe})$, was obtained from the certified Health Laboratory results. Data on the concentration of iron $(\mathrm{Fe})$ in water is a TDS meter that describes the number of dissolved substances in Parts Per Million (PPM) or equal to milligrams per Liter (mg/l).

\section{RESULT AND DISCUSSIONS}

\section{A. Measurement Concentration}

In surface water, rarely found $\mathrm{Fe}$ intensities more significant than $1 \mathrm{mg} / \mathrm{L}$, but in groundwater, $\mathrm{Fe}$ concentrations can be much higher. This high concentration of Fe can be felt and can stain cloth, kitchen utensils, and 
sanitation tools. Whereas in groundwater with high alkalinity, it usually has a low iron concentration because it is oxidized and settles at a high degree of acidity. Groundwater containing iron and high organic matter will form complex bonds difficult to settle with aeration [33].

This study focused on iron contained in shallow wells that are still used by the community. From 10 samples that have tested at Makassar Health Laboratory, it turns out that shallow well water in Pangkep has the highest concentration of iron (Fe) before treatment of $22.21 \mathrm{mg} / \mathrm{l}$ contained in the first water sample then the lowest iron $(\mathrm{Fe})$ is obtained for $12.32 \mathrm{mg} / \mathrm{l}$ contained in the third water sample number.

The Manado sample showed quite different results seen in Figure 3. The Pangkep sample was seen from the iron content $(\mathrm{Fe})$ concentration from the measurement results before treatment obtained by $23.69 \mathrm{mg} / \mathrm{l}$ for the seventh water sample with the highest iron $(\mathrm{Fe})$ content. Then for the lowest iron $(\mathrm{Fe})$ content obtained $22.22 \mathrm{mg} / \mathrm{l}$ contained in the first sample.

From these results, it can see in the differences in the initial measurements of the study conducted at different places and conditions. High-temperature conditions at the study site can also cause decreased levels of dissolved oxygen in the water. An increase in water temperature can describe the degree of mineral solubility so that the solubility of $\mathrm{Fe}$ in high water. Therefore, there will be differences in the measurement results obtained.

The high iron content in wells can be due to the higher mineral rock content around this well compared to other well locations because it is in a relatively higher plain. Besides that, the degree of acidity of well water is the lowest or acidic compared to other wells. The more acidic the degree of acidity, the more metals will dissolve, including iron. This can be caused by the low dissolved oxygen content in the well. As explained in theory above, dissolved oxygen in the neutral degree of acidity conditions will oxidize ferrous to ferric and form sediment. The lower the concentration of dissolved oxygen, the higher the concentration of dissolved iron. In other wells, the low dissolved iron content can be due to the high concentration of dissolved oxygen in well water [34]. High temperatures will cause a decrease in the level of oxygen in the water. An increase in water temperature can also describe the degree of solubility of minerals so that the solubility of iron $(\mathrm{Fe})$ concentration in water becomes high [35], [36].
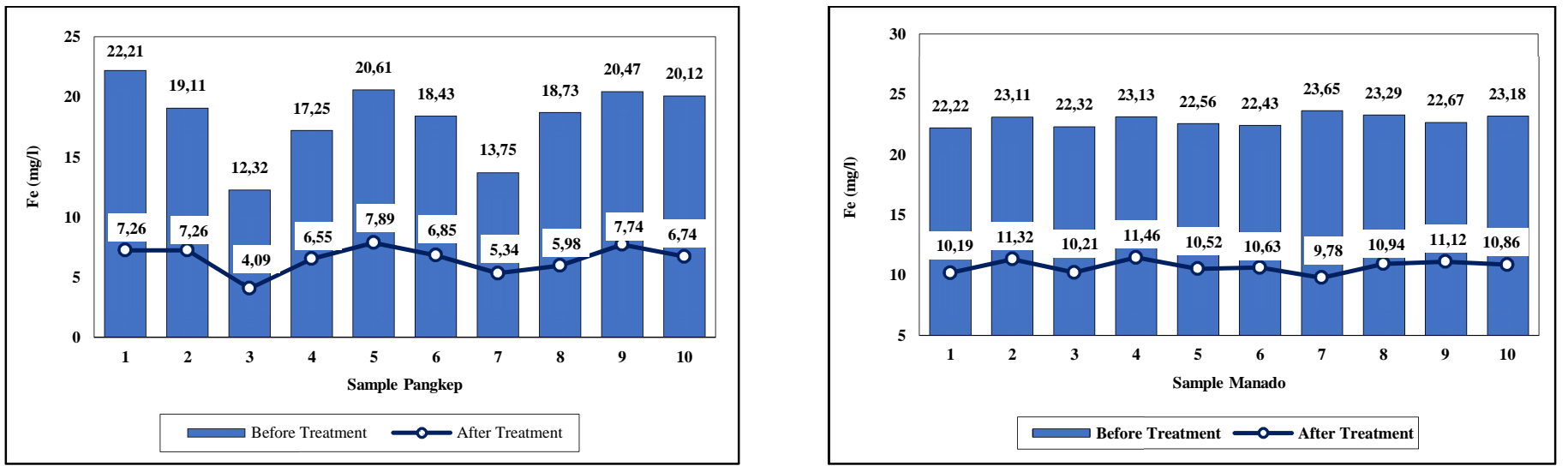

Fig. 3 Concentration Fe (mg/l) before and after treatment (Multiple Tray Aerator and Rapid Sand Filter)
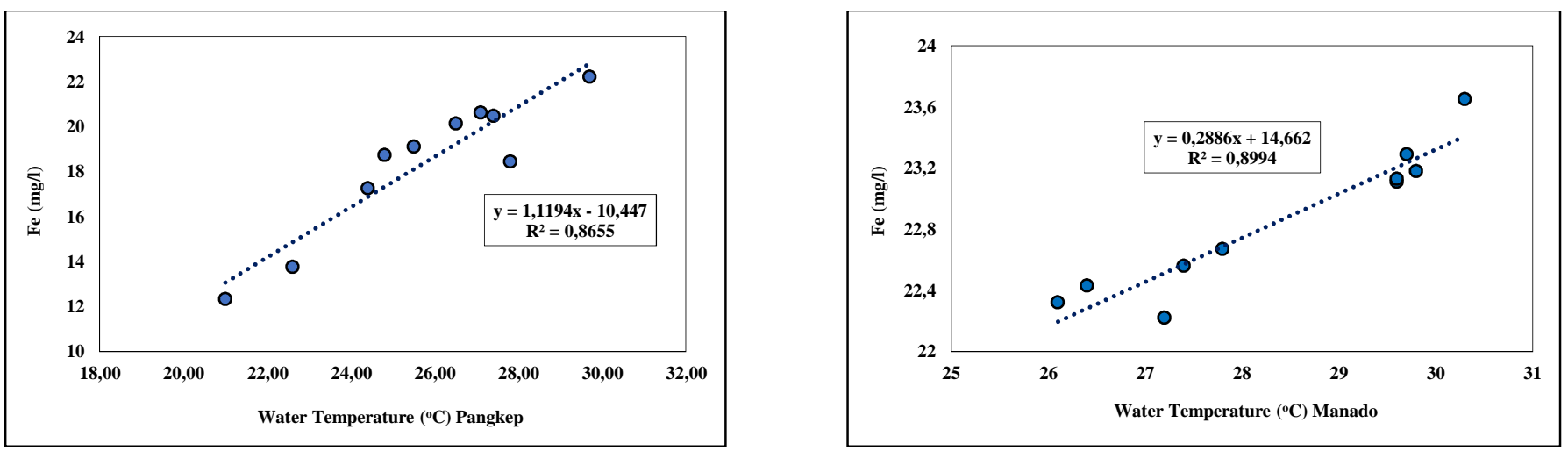

Fig. 4 The relationship of $\mathrm{Fe}(\mathrm{mg} / \mathrm{l})$ with water temperature $\left({ }^{\circ} \mathrm{C}\right)$

The measurement results after the aeration and filtration process in the Pangkep sample obtained $7.89 \mathrm{mg} / \mathrm{l}$ for the highest found in the fifth sample, then the lowest obtained by $4.09 \mathrm{mg} / \mathrm{l}$ found in the third sample. Furthermore, for the Manado sample, the highest content of $11.46 \mathrm{mg} / \mathrm{l}$ was found in the fourth sample, and the lowest found in the seventh sample was $9.78 \mathrm{mg} / \mathrm{l}$. In natural water systems and water treatment systems, iron compounds vary depending on the acidity of water. Changes in iron compounds in natural water systems under conditions of reduction, manganese, and iron, in general, have a valence of two that are soluble in water. Therefore, in the water treatment system, the two-valence 
manganese and iron compounds are oxidized in various ways to become compounds with a higher valence, which is not soluble in water so that they can be easily separated physically. There are three methods commonly used to control the presence of Fe in drinking water supply, namely precipitation followed by filtration, ion exchange, and stabilization of iron in solution and dispersing agents to prevent the deposition of these metals [37], [38].

The calculation results show that the average measurement of the concentration of iron $(\mathrm{Fe})$ in the water at the Pangkep location before the treatment process, namely Tray Aerator and Rapid Sand Filter is obtained $18.30 \mathrm{mg} / \mathrm{l}$ then after going through the process obtained results of 6.57 $\mathrm{mg} / \mathrm{l}$. Research conducted showed a difference of $11.73 \mathrm{mg} / \mathrm{l}$ between before and after the treatment process. Then for the concentration of iron $(\mathrm{Fe})$ in water samples at the Manado location before the treatment process, Tray Aerator, and Rapid Sand Filter obtained an average value of $22.86 \mathrm{mg} / \mathrm{l}$ then; after going through the process, the results obtained were $10.70 \mathrm{mg} / \mathrm{l}$. Research conducted showed a difference of $12.15 \mathrm{mg} / \mathrm{l}$ between before and after the treatment process.

Iron content in groundwater, especially in well water, is common. Groundwater, which generally has a high concentration of carbon dioxide, can cause anaerobic conditions. This condition causes the concentration of insoluble iron form $(\mathrm{Fe} 3+)$ reduced to iron, which dissolves in the form of two-dimensional ions $(\mathrm{Fe} 2+)$. The concentration of iron in groundwater varies from 0.01- 25 $\mathrm{mg} / \mathrm{l}[39]$.

The temperature of a water body is influenced by seasons, latitude, the altitude from sea level, time of day, air circulation, and depth of water bodies. Temperature changes affect the physical, chemical, and biological processes of water. Temperature also plays an essential role in controlling aquatic ecosystems. An increase in temperature can cause a decrease in the solubility of gases in water. Besides, the increase in temperature can increase the metabolism and respiration of aquatic organisms, which causes an increase in oxygen consumption. This can be seen in Figure 4, which shows the strong relationship between temperature and $\mathrm{Fe}$ concentration at the study site.

The dissolved oxygen content can decrease if the temperature in the water becomes high. The high solubility of $\mathrm{Fe}$ content in water can be seen from the increase in temperature, which causes the level of solubility of mineral elements in the water. A low dissolved oxygen concentration causes low metal solubility, settling comfortably to the bottom of the sediment.

\section{B. Decreased Concentration}

Filtration or filtering in this study is a form of treatment to separate solids dissolved in water. In this process, filtration with gravel media, coconut shell charcoal, and sand. Gravel serves to filter out coarse particles in the water. Charcoal functions to filter or remove odors, colors, and pollutants in water and purify water. The sand serves to filter mud, soil, and large/small particles in water. The principle works because the water to be filtered flows from the bottom up through the sand layer because of the gravitational force, then solid particles which will be separated are held in the sand.
The results of the reduction seen in Figure 5 shows that the tool used is quite stable in reducing Fe content in water samples at two different study sites. The average percentage reduction in the concentration of iron (Fe) for the Pangkep sample was $64.06 \%$, then for the Manado sample, it was $53.16 \%$. From these results, the difference between the two sample locations was $10.90 \%$.

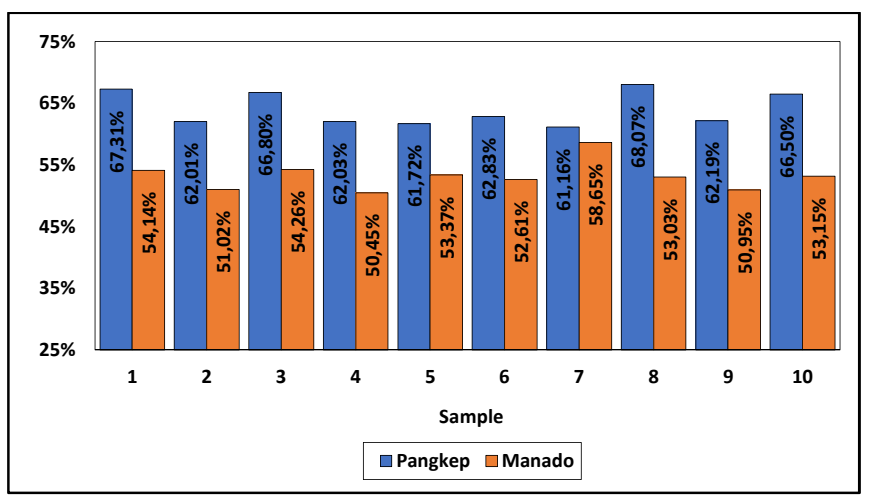

Fig. 5 Decreasing Fe with Aeration and Filtration

This shows that the contact time of a lot of oxygen penetration at the time of this study determined by the contact time flowed through the shower, water through aeration. The presence of water spray then into the settling basin, to make water contact with air longer with a small spray and to widen that makes the iron ion binding process occurs with dissolved oxygen (ferrous) into an insoluble form (ferric). The process then is continued to precipitate and partly enter the filtration treatment section. In the aeration process, oxygen in the air will react with Ferus compounds and dissolved manganous to change into ferric (Fe) and insoluble manganic oxide hydrates. After that, proceed with sedimentation or filtration. It should be noted that oxidation of iron compounds in water does not always occur quickly.

Aeration is a water treatment by adding oxygen to water. The addition of oxygen is done to eliminate an excess parameter in water so that the parameter concentration will be reduced or can eliminate. In practice, there are two ways to add oxygen to water: putting air into water and or forcing water up to contact oxygen. The problem that often occurs when utilizing groundwater is the mineral content. Types of groundwater mineral content are quite diverse, including mercury, iron, manganese, sodium, copper, and zinc [40]. In bodies of water and geological layers on the ground, iron is an element that is almost certain to be found in these places. In general, the iron component in water can dissolve [41], [42]. The content of $\mathrm{Fe}$ ions in deep well water can range between 5-7 mg/l [43], [44]. While the clean water iron content standard based on the Republic of Indonesia Minister of Health Regulation 2017 is a maximum of 1.0 $\mathrm{mg} / \mathrm{l}$. soil structure conditions greatly influence the high or low content of $\mathrm{Fe}$ in water. The content of chemical elements in water is very dependent on the geological formation where the water is located and the geological formation where it passes through water. For example, if during the water through a rock containing iron, the water will automatically provide iron and other elements. The size of the dissolved material depends on the length of water in 
contact with rocks. The more extended water interactions with rocks, the higher the elements dissolved in it [45].

The shallow groundwater system was replenished by rainwater permeation. In dense residential areas, the sanitation system is not right, or water from septic tanks can seep into aquifers and contaminate shallow groundwater [46]. Seepage water or septic tanks can be capable of decreasing the level of deep shallow groundwater, especially in the dry season. As a result, many pollutants that enter the aquifer system. When the rainy season arrives, the pollutants will dissolve. Thus, the process goes on, so that shallow groundwater saved by domestic waste, proven that a lot of residents' well water can physically be seen. At the same time, most people have no other choice but to use groundwater or well water to meet their daily needs. They are namely cooking, washing, bathing, and drinking because groundwater or well water is one of the main alternatives for the community to get clean water cheaply to meet their daily needs.

The quality of groundwater is also affected by the soil itself because water that passes through the soil can dissolve the minerals found in the soil. The quality of groundwater in various regions varies according to local soil characteristics. Groundwater usually has a relatively high iron content. Suppose groundwater encounters air and undergoes oxygenation. In that case, the ferric ions in ferric hydroxide [Fe $(\mathrm{OH}) 3]$, which are abundant in groundwater, will be oxidized to Ferro and immediately experience precipitation (precipitation) and form a reddish color in the water. Water carries chemical elements in the course of water into the soil, and because of its easily oxidized nature, it causes chemical changes in the soil or geological material [47]. The presence of iron in the earth's crust occupies the fourth largest position. Iron found in the form of ferrous cations $(\mathrm{Fe} 2+)$ and ferric $(\mathrm{Fe} 3+)$. In natural waters with a $\mathrm{pH}$ of around seven and sufficient dissolved oxygen levels, soluble ferrous ions oxidized to ferric ions. Iron content is present in water as secondary ions (secondary constituents) with levels between $0.01-10.0(\mathrm{mg} / \mathrm{l})$ [48].

\section{CONCLUSIONS}

The reduction obtained was quite good even though the $\mathrm{Fe}$ value produced was not included in the proper clean water standard. For people who have water with high $\mathrm{Fe}$ levels and want to reduce $F e$ levels, it is better to use more extended aeration and Filtration, more specifically, to determine the ratio of aeration and filtering sizes. Considering the temperature of the water source, that is enough to affect the mineral content in water, including $\mathrm{Fe}$ content. Those who wish to continue this research should pay attention to the tool's type and ability and design a more accurate model to minimize energy and cost and a more solid form.

\section{ACKNOWLEDGMENT}

This study was made possible by the financial support of the Ministry of Health of the Republic of Indonesia, which provided funds in the 2018 Higher Education Superior Research Program (No. HK.01.07/III/00850/2018).

\section{REFERENCES}

[1] H. Frumkin, J. Hess, G. Luber, J. Malilay, and M. McGeehin, "Climate change: the public health response," Am. J. Public Health, vol. 98, no. 3, pp. 435-445, 2008.

[2] I. S. Zektser, "Groundwater as a Component of the Environment," in Geology and Ecosystems, Springer, 2006, pp. 91-105.

[3] Ronny, Ruslan, and Hasani, "Clean Water in Urban Areas: Influence on Public Behavior, Knowledge and Attitudes," Int. J. Sci. Technol. Res., vol. 9, no. 3, pp. 5040-5044, 2019.

[4] World Resources Institute, World Resources: People and ecosystems: The fraying web of life. Washington, D.C.: World Resources Institute, 2000.

[5] M. D. Falah, "Geoelectric Method Implementation in Measuring Area Groundwater Potential: A Case Study in Barru Regency," Int. J. Environ. Eng. Educ., vol. 2, no. 1, pp. 1-8, 2020.

[6] Ronny, Erlani, and Jasman, "Level of Correlation in the Depth of Groundwater Wells: Iron and Chloride," Indian J. Environ. Prot., vol. 39, no. 8, pp. 746-751, 2019.

[7] Ronny. and A. H. Hasim, "Effectiveness of Multiple Tray-Aerators in Reducing Iron ( $\mathrm{Fe}$ ) Water Wells in Gowa Regency, Indonesia," Ecol. Environ. Conserv., vol. 24, no. 1, pp. 22-25, 2018.

[8] Ronny, G. D. Dirawan, M. Ardi, and B. Rauf, "Strategies for increasing Awareness on Environmental Sanitation in Maintenance Knowledge Society Environment in Makassar," Man India, vol. 96, no. 5, pp. 795-803, 2015.

[9] M. I. Ali, A. H. Hasim, and M. R. Abidin, "Monitoring the Built-up Area Transformation Using Urban Index and Normalized Difference Built-up Index Analysis," Int. J. Eng. Trans. B Appl., vol. 32, no. 5, pp. 647-653, 2019, doi: 10.5829/ije.2019.32.05b.04.

[10] M. I. Ali, G. D. Dirawan, A. H. Hasim, and M. R. Abidin, "Detection of Changes in Surface Water Bodies Urban Area with NDWI and MNDWI Methods," Int. J. Adv. Sci. Eng. Inf. Technol., vol. 9, no. 3, pp. 946-951, 2019.

[11] M. Tomaszewska and S. Mozia, "Removal of organic matter from water by PAC/UF system," Water Res., vol. 36, no. 16, pp. 41374143, 2002.

[12] S. Mozia, M. Tomaszewska, and A. W. Morawski, "Application of an ozonation-adsorption-ultrafiltration system for surface water treatment," Desalination, vol. 190, no. 1-3, pp. 308-314, 2006.

[13] S. S. Adham, V. L. Snoeyink, M. M. Clark, and J. Bersillon, "Predicting and verifying organics removal by PAC in an ultrafiltration system," Journal-American Water Work. Assoc., vol. 83, no. 12, pp. 81-91, 1991.

[14] C. H. Tan and H. Y. Ng, "A novel hybrid forward osmosisnanofiltration (FO-NF) process for seawater desalination: Draw solution selection and system configuration," Desalin. water Treat., vol. 13, no. 1-3, pp. 356-361, 2010.

[15] S. Yüksel, N. Kabay, and M. Yüksel, "Removal of bisphenol A (BPA) from water by various nanofiltration (NF) and reverse osmosis (RO) membranes," J. Hazard. Mater., vol. 263, pp. 307-310, 2013.

[16] S. Zhao, L. Zou, and D. Mulcahy, "Brackish water desalination by a hybrid forward osmosis-nanofiltration system using divalent draw solute," Desalination, vol. 284, pp. 175-181, 2012.

[17] V. Uyak, I. Koyuncu, I. Oktem, M. Cakmakci, and I. Toroz, "Removal of trihalomethanes from drinking water by nanofiltration membranes," J. Hazard. Mater., vol. 152, no. 2, pp. 789-794, 2008.

[18] S. Ebrahim, S. Bou-Hamed, M. Abdel-Jawad, and N. Burney, "Microfiltration system as a pretreatment for RO units: Technical and economic assessment," Desalination, vol. 109, no. 2, pp. 165-175, 1997.

[19] C. C. Mólgora, A. M. Domínguez, E. M. Avila, P. Drogui, and G. Buelna, "Removal of arsenic from drinking water: a comparative study between electrocoagulation-microfiltration and chemical coagulation-microfiltration processes," Sep. Purif. Technol., vol. 118, pp. 645-651, 2013.

[20] S. Rodriguez-Mozaz et al., "Pharmaceuticals and pesticides in reclaimed water: efficiency assessment of a microfiltration-reverse osmosis (MF-RO) pilot plant," J. Hazard. Mater., vol. 282, pp. 165$173,2015$.

[21] Z. Amjad, Reverse osmosis: membrane technology, water chemistry, and industrial applications. Van Nostrand Reinhold New York, 1993.

[22] A. Altaee, G. Zaragoza, and H. R. van Tonningen, "Comparison between forward osmosis-reverse osmosis and reverse osmosis processes for seawater desalination," Desalination, vol. 336, pp. 50$57,2014$. 
[23] D. C. Andreasen and W. B. Fleck, "Use of bromide: chloride ratios to differentiate potential sources of chloride in a shallow, unconfined aquifer affected by brackish-water intrusion," Hydrogeol. J., vol. 5, no. 2, pp. 17-26, 1997.

[24] Ronny, M. I. Arif, and H. B. Notobroto, "Water Pollution Index: Measurement of Shallow Well Water Quality in Urban Areas," Int. J. Environ. Eng. Educ., vol. 1, no. 3, pp. 75-81, 2019.

[25] J. R. Fraenkel and N. E. Wallen, How to Design and Evaluate Research in Education, 7th ed. New York: McGraw-Hill Higher Education, 2009.

[26] F. N. Kerlinger and H. B. Lee, Foundations of Behavioral Research, 4th ed. New York: Holt, Rinehart and Winston, 2000.

[27] Bordens, Kenneth S. and Abbott, Bruce B., Research Design and Methods: A Process Approach, 9th ed. New York: McGraw-Hill Education, 2014.

[28] Roscoe, John T., Fundamental Research Statistics for the Behavioral Sciences, 2nd ed. New York: Holt, Rinehart and Winston, 1975.

[29] Diehl, P L. and L. R. Gay, "Research Methods for Business and Management," New York McMillan, 1992.

[30] Ronny, Irfai, D. Mahyudin, and Jasman, "Banana Stem Charcoal as Adsorbents Reduce Water Hardness Levels," Int. J. Environ. Eng. Educ., vol. 1, no. 1, pp. 1-6, 2019, doi: 10.5281/zenodo.2633483.

[31] American Society of Civil Engineers (ASCE) and American Water Works Association (AWWA), Water Treatment Plant Design. New York: McGraw-Hill Professional, 2012.

[32] H. J. Pöpel, Aeration and Gas Transfer. Division of Sanitary Engineering, Delft Univer sity of Technology, 1972.

[33] S. R. Qasim, E. M. Motley, and G. Zhu, Water works engineering: planning, design, and operation. Prentice Hall, 2000.

[34] T. D. Jickells et al., "Global iron connections between desert dust, ocean biogeochemistry, and climate," Science (80-. )., vol. 308, no. 5718, pp. 67-71, 2005.

[35] H. Pörtner, "Climate change and temperature-dependent biogeography: oxygen limitation of thermal tolerance in animals," Naturwissenschaften, vol. 88, no. 4, pp. 137-146, 2001.
[36] J. D. Hem, Study and interpretation of the chemical characteristics of natural water, vol. 2254. Department of the Interior, US Geological Survey, 1985.

[37] C. Binnie, M. Kimber, G. Smethurst, and G. Smethurst, Basic water treatment. Thomas Telford, 2002.

[38] S. D. Faust and O. M. Aly, Chemistry of water treatment. CRC press, 1998.

[39] C. N. Sawyer and P. L. McCarty, "Chemistry for environmental engineers," New York. Mc Graw-Hill B. Co., 1978.

[40] D. Hillel, Soil and water: physical principles and processes. Elsevier, 2012.

[41] P. Lavelle and A. V Spain, Soil ecology. Springer Science \& Business Media, 2001.

[42] J. M. Tisdall and J. Oades, "Organic matter and water-stable aggregates in soils," J. soil Sci., vol. 33, no. 2, pp. 141-163, 1982.

[43] N. S. Rao, "Iron content in groundwaters of Visakhapatnam environs, Andhra Pradesh, India," Environ. Monit. Assess., vol. 136, no. 1-3, pp. 437-447, 2008.

[44] T. Lupaşcu, M. Ciobanu, and V. Boțan, "Removal of divalent iron and manganese ions and hydrogen sulfide from groundwater," Chem. J. Mold., vol. 9, no. 2, pp. 58-61, 2014.

[45] C. J. Bronick and R. Lal, "Soil structure and management: a review," Geoderma, vol. 124, no. 1-2, pp. 3-22, 2005.

[46] Ronny, A. H. Hasim, Ronny., and A. H. Hasim, "Effectiveness of multiple tray-aerators in reducing Iron $(\mathrm{Fe})$ water wells in Gowa Regency, Indonesia," Eco. Env. Cons., vol. 24, no. 1, pp. 22-25, 2018.

[47] N. Kresic and Z. Stevanovic, Groundwater hydrology of springs: Engineering, theory, management, and sustainability. Butterworthheinemann, 2009.

[48] D. K. Todd and L. W. Mays, "Groundwater hydrology edition," Welly Inte, 2005. 